dependents, and questions whether the benefits of the services of such practitioners might be ultimately extended to others in better circumstances. One might as well question whether the benefits of the elementary schools might be extended to the upper classes, or the benefits of the Poor-law medical service to well-paid artisans. If the whole-time salaried service were really the boon to humanity that Mr. Parker and others believe it to be, should we not find it being first introduced for the benefit of the rich and later being extended to the poor? When the mover and seconder of a Bill for the establishment of a whole-time medical service, be they members of the Labour party or any other party in Parliament, explain that they for themselves and their wives and families are expecting to make use of the benefit thus provided, the scheme might be regarded as within the range of practical politics. The present schemes for establishing such a service are really proposals made by superior persons for the good of the "lower orders," whose poverty would alone compel them to submit to the discipline of State medical officials, a discipline from which our legislators themselves and the wealthy classes generally would secure freedom by the payment of money. Mr. Parker quotes with satisfaction a recent decision of the High Court that a parent might be imprisoned for refusing to submit his child to a surgical operation recommended by a doctor. Does Mr. Parker imagine that a High Court judge will ever hare the opportunity of imprisoning or fining a peer or a member of the House of Commons for not allowing a surgeon to remove his child's adenoids or a bacteriologist to inject it with a tuberculin? If a judge is found on appeal to a still higher court to have the power at the present time to deal out justice of this sort to the poor there can be little doubt that further legislation will in due time deprive him of it.

It would be a good criterion of the ralue of any suggested legislation in connexion with medicine to consider whether we are proposing to extend privileges already possessed by the independent classes to those who are in porerty, or to set up for those in straitened circumstances so-called benefits of which the wealthy classes would never arail themselves. Measured by such a test the wholetime salaried medical service will, I believe, be regarded by the great majority of the public and the profession as unacceptable.

I have no scruples in thus pointing out to Mr. Parker that his panacea for all medical evils is impracticable, for $I$ am sure I can show him that most of the real improvements he desires are attainable independently of his cherished whole-time service. A doctor on a panel can refer his patient to a consultant, a specialist, or a bacteriologist, just as easily and profitably as could a member of a whole-time service. The provision of sufficient hospital accommodation throughout the kingdom, the making of it accessible to all classes who want it, and the aid, if need be, of the State in securing these objects, do not in the least depend upon the patient before or after admission to the wards being under the care of a whole-time servant of the State. For great numbers of insured persons and others these supplementary medical necessities are already provided in a haphazard way by philanthropic effort through the medium of our voluntary hospitals. There is, without doubt, room for considerable extension and for much more systematic administration. The aid of the State is almost certainly necessary in many directions. A chief obstacle to the attainment of these desirable aims is the clamour of a small section of reformers who insist, in season and out of season, that the only possible way of remedying existing evils is the quite impossible way of transforming all that part of the profession which treats the industrial classes into a State service of whole-time salaried officers.

No one stops progress so much as he who insists that the impracticable must first be achieved.

I am, Sir, yours faithfully,

Harley-street, W., Mareh 15th, 1914. LAURISTON E. SHAW.

\section{THE MILWARD FUND: A LETTER OF THANKS.}

To the Editor of THE LANCET.

SIR,-Will you allow me, through THE LANCET, to express a little of the gratitude I feel to all those who have so generously helped me and my boys in our need?

Of the practical sympathy shown us, you have just published some of the material results; and. only those with children to equip for their work in life can realise the load of responsibility of which I have been relieved by the assurance of good education for my boys, and of the means to meet their expenses during their apprenticeships.

I cannot hope to express adequately my appreciation of this, and even less can I do so of the constant reminders of sympathy and encouragement that so many have given us since our loss.

I can only trust that our gratitude may meet with the same understanding that our many friends have shown us in our sorrow.

Believe me, yours faithfully, E. S. DoRothy MILWARD.

5, Glossop-road, Cardiff, March 21st, 1914.

\section{AN ASSOCIATION OF TUBERCULOSIS MEDICAL OFFICERS. \\ To the Editor of THE LANCET.}

SIR,-The letter on the above subject in your issue of March 2lst suggests to me four points:-

1. Sanatorium and consumption hospital residents and pathologists to be included. There would then result an association somewhat like the German one of Tuberkulose Aerate, excellent reports of whose meetings reach one from time to time. It must be confessed that some tuberculosis officers have been appointed upon insufficient experience and scarcely know their subject.

2. None but "tuberculosis whole-timers"-i.e., those who deal with no other disease-to be eligible for any sort of membership.

3. Coöperation with the existing Irish association to be promoted in every possible way, perhaps later by establishment of a common journal ; separate space in this should be given to each of the four countries for local news.

4. Those " tuberculosis whole-timers" who served on, or furnished memoranda to, the recent Departmental Committee on Tuberculosis to be invited to join with representatives of tuberculosis officers to form a committee of inauguration and general management.

I enclose my card and remain, Sir, Yours faithfully

March 23rd, 1914. TUBERCULOSIS OFFICER.

Victoria Hospital, Frome.--It has been decided to carry out extensions and improvements at this hospital in order that the institution may be placed on the official list of the Somerset County Insurance Committee, and thus be in a position to treat patients suffering from tuberculosis. The cost of the scheme is estimated at $£ 1250$. 